\title{
Qualification of Adult Educators in Europe: Insights From the Portuguese Case
}

\author{
Catarina Paulos \\ University of Lisbon \\ Institute of Education \\ Alameda da Universidade, 1649-013 Lisbon, Portugal \\ E-mail: catarina.paulos@campus.ul.pt
}

Received: 02 February 2015; Accepted: 24 March 2015; Published online: 30 April 2015

\begin{abstract}
This article explores the role of the European Union in defining an adult education policy and the way European countries appropriate those guidelines and implement them in their realities. These policies have been widening and diversifying adult education, creating the necessity of qualifying educational professionals. With the implementation of some adult education political measures, new educational practices were developed and new professional activities were born. This investigation is about the qualification of adult educators working in the processes of recognition of prior learning.
\end{abstract}

Keywords: Adult education, adult educators, qualification, lifelong learning, recognition of prior learning, qualitative approach, biographical interview

\section{Bibliographical notes:}

Catarina Paulos is a $\mathrm{PhD}$ student in Education at the Institute of Education at the University of Lisbon, Portugal. Her research interests focus on adult education, education policies and sociology of education. 


\section{Introduction}

Recently in Europe, with the increasing interest in the adult education field and in the lifelong learning perspective, adult educators have also received increased attention. In this way, the qualification of those who carry out procedures in the field of adult education has received an increase of policy attention over the past decade (European Commission, 2006; European Commission, 2007; Research voor Beleid and PLATO, 2008; Research voor Beleid, 2010). Several authors have pointed out that the quality of work developed in adult education is dependent on the abilities and competences of the practitioners (Jütte, Nicoll and Olesen, 2011; Egetenmeyer and Käpplinger, 2011; Travers and Harris, 2014).

In light of this, this article intends to show the results of an investigation about the process of qualification of adult educators in a European country. The data used are from research integrated in a $\mathrm{PhD}$ programme about the qualification of adult educators working in recognition of prior learning. This research aims to understand the professional paths of adult educators from the time they started working until they got the job as recognition of prior learning professionals, their process of qualification and ways of learning and training. Several research questions were posed, particularly: Who are these adult educators in terms of gender, initial and continuing qualifications, and previous professional development? What are the competences of the recognition of prior learning professionals? How do they learn to work in the recognition of prior learning?

This article presents firstly a brief view of the adult education political framework in the European Union (EU), in which the recognition of prior learning is one of their educational strategies. After this, the qualification process of professionals for adult learning in Europe is discussed. The last section highlights some results from an investigation about the qualification of adult educators who were working in the recognition of prior learning process in Portugal.

\section{European Union and Adult Education Political Framework}

In the last few decades, the educational and training policies formulated at a national level have been in line with the priorities and targets set by the European Union. National educational policies are the result of the articulation between the priorities of EU policies and the creation of models of interpretation of problems and common action norms, assisting to the Europeanisation and the construction of a European global referential for the national educational policies (Antunes, 2008).

In the early 1970s the first initiatives in the field of education at a community level were conceived (Antunes, 2008). In the middle of the 1980s, with the European Single Act, there was an intensification of this intervention, with the creation of Community Action Programmes (1986-1992). At this time, there were processes of institutionalisation and consolidation of education as an area of cooperation, action and community policy intervention and the member states built guidelines and common actions standards to their national education policies.

In 1992, the European Union Treaty represented a big step on this path with the inclusion of Article 126 about the legitimacy of the competence and the action of the European Union in the field of education. Two White Papers were published in the 1990s, one titled "Growth, competitiveness, employment. The challenges and ways forward into the 21st century" (Commission of the European Communities, 1993), and the other "Teaching and learning: Towards the learning society" (Commission of the European Communities, 1995). Both documents highlighted the core role of 
education and training in the context of the priorities and policies of the European Union concerning the increasing focus on promoting competitiveness of the European economy. As a matter of fact, the issues concerning human resources played a central role in the European integration process, given the position assigned them in the competitiveness of the European Union economy.

Education has been reordered around policies and practices that consolidate a liberal-productive model and a utilitarian-instrumental model of organising educational relationships, processes and institutions (Antunes, 2008). Lifelong learning became the basic principle of the discourse about education and training policies in the European Union. In October 2000, the European Commission published the Memorandum on Lifelong Learning, despite that the concept of lifelong learning had already appeared when European Union declared 1996 the European Year of Lifelong Learning. The lifelong learning concept introduced some changes in the conceptualisation of adult education. One result of this approach was the acknowledgement of different types of knowledge and several learning contexts, such as formal, non-formal and informal. Another consequence was the change of the focus from inputs to outputs, which means from knowledge to competence (Freynet, 2008), a concept that has gained a core importance in contemporary society.

The lifelong learning approach highlights the role of the individual in taking advantage of the educational offer and in the building of a life path that improves employability. This approach leaks the idea that an individual is the manager of his/her competences and his/her employment depends on the capacity to adjust those competences to the labour market, which can be understood as an "instrument of adaptation rather than emancipation" (Biesta, 2012). A few decades ago, in the 1970s, the educational process would accompany people throughout their life cycle, in which an individual was the subject of the training (Canário, 2008), therefore education was viewed as a tool for the integral development of the human being and vital to individual and social emancipation. Considering this perspective, the individual had an active intervention in society, and he/she in association with others, could lead to social change processes. Nowadays, education is viewed as a tool to fulfil the labour market needs, in a process of adaptation of the individual to the demands of the economy. The capacity of employability has become a core issue, and it is viewed essentially as an individual problem instead of being viewed as a collective issue. One of the guidelines of the lifelong learning strategy is the recognition of prior learning from non-formal and informal settings, a process that has been implemented in several European countries, including Portugal. The recognition of prior learning offers a process-oriented approach for recognising and valuing what people have learned in their lives and it is "an important cornerstone of lifelong learning" (Duvekot, 2014).

\section{Qualifying Professionals for Adult Learning in Europe}

In a lifelong learning context, an adult educator is not only a knowledge provider, but he is also faced with a wide range of situations, which can mobilise different skills and competences. For example, adult educators can develop different tasks, such as personal and vocational guidance, accreditation of prior learning, pedagogical accompaniment, teaching, building learning situations or designing and making learning tools (Freynet, 2008).

Adult educators are a professional category that includes several kinds of professionals with different knowledge, skills and abilities. The data of the European Research Group on Competences in the Field of Adult and Continuing Education 
(with contributions from Austria, Sweden, Denmark, the UK, the Netherlands, Germany, Poland, Italy, France and Portugal) indicate that adult educators can work in four domains, which involve different work content and qualities (Van Dellen and Van der Kamp, 2008). These work domains, which appeared in this document, are vocational education, corporate and functional education, social and moral education, and cultural and arts education.

The adult education field is marked by an enormous variety of working contexts and due to this adult educators fulfil a broad range of tasks and activities (Research voor Beleid and PLATO, 2008). The ALPINE study, which collected data from 32 countries, shows also that professionals involved in adult learning have a variety of backgrounds and a considerable part of them started working without specific training to become an adult educator. Those professionals also have a wide variety of qualifications, varying from certificates of participation in a training course to diplomas and academic degrees. In light of this, adult educators need particular competences in order to carry out their wide range of professional tasks. To fulfil their job requirements, adult educators should have access to suitable qualification and continuous professional development.

In Europe there is no regulated qualification in the field of adult educators (Bechtel, 2008). But Egetenmeyer (2010) remarks that there are two typical ways of qualifying as an adult educator: through university programmes with an academic degree; and through further education programmes, often offered by adult education institutions. According to some authors such as Lattke and Nuissl (2008), it is needed to increase the knowledge about the activities developed by adult educators, "the skills that they possess or that they still need to improve" (p. 13). A diagnosis of all adult education activities developed on a full-time and part-time basis, and the qualifications of their professionals would be important, because it would allow for the creation of a competences development framework. It is important to have knowledge about the adult educators' needs in order to invest in their further professional development.

The qualification of professionals of adult learning is a vital determinant of the quality of adult learning (Research voor Beleid, 2010). However, most of the initiatives that have been taken to improve the professional situation of teaching staff have concentrated mainly on school teachers or in the initial vocational education staff. Educational staff, who are working outside the formal system, have been forgotten. This happens due to a "very low degree of regulation and a very high degree of diversity and complexity regarding structures, types of learning offers and types of actors involved," (Lattke and Nuissl, 2008).

The report "Key competences for adult learning professionals" (Research voor Beleid, 2010) defined seven generic competences considered relevant for professionals carrying out all activities in the adult learning sector. Such competences vary from being a fully autonomous lifelong learner to being a motivator and being able to deal with heterogeneity and groups. Alongside the generic competences which all adult learning professionals should possess, there were defined specific competences directly involved in and supportive for the learning process, which should be mobilised in specific activities carried out by adult educators (Research voor Beleid, 2010).

The European Qualifications Framework (EQF) appeared as an instrument that could help the European countries to find a common basis for the establishment of competences, profiles and standards for professionals who are working in the adult 
education field (Bechtel, 2008). The EQF comprises eight levels, covering the competences acquired throughout the several levels of academic, professional or vocational education and training. This system focuses not only on formal qualifications, but also on learning outcomes acquired in formal, non-formal and informal contexts, and these learning outcomes are based on competences achieved by the learner.

Adult educators' qualification has a key role in the implementation of efficient adult education programmes, being therefore an important point of several European policy documents in the field of lifelong learning (Research voor Beleid, 2010). The European Commission urges member states to implement initial and continuing professional development measures to qualify people working in the field of adult education (Nuissl and Lattke, 2008).

\section{Qualifying Professionals for Adult Education in Portugal}

In Portugal, over the past three decades, the education of adults has been marked by discontinuous educational policies (Lima, 2008). After Portugal's democratic revolution in 1974, there was a boom of popular social movements that have extended to adult education. In this context, animators, local organisers and literacy teachers were the main agents involved in adult education processes. These adult educators didn't have specific training; then "it was the experience of working with communities and the attendance of continuing education courses (poorly structured and sporadic)" (Guimarães, 2009), implemented by the General Directorate of Permanent Education, that enabled the development of differentiated knowledge. At the time, adult educators worked to promote democracy and develop autonomy, equal opportunities and social emancipation, influenced by UNESCO's lifelong education approach and its vision of education as a means to self-development of individuals and as a means for "learning to be" (Faure et al., 1972). At this time although adult educators had a common profile considering ability, experience and practice, they differed in terms of basic professional training, personal history and path of social intervention. These differences "explained the non-creation of a single, institutionalised career of adult educator" (Guimarães, 2009).

In 1986 the Basic Law for the Education System was approved, which defined adult education as a subsector incorporating two offers: second-chance education and out-of-school education. The first offer was carried out mainly by teachers. Outof-school education was implemented by educators who received a grant. In both offers, and just as had happened before, these adult educators were quite heterogeneous, comprised of people with different professional qualifications and experience and with inconsistent continuing training (Guimarães, 2010).

Between 1995 and 2002 the government adopted measures to promote adult education, especially of the active population which had lower educational levels than other EU and OECD countries (Guimarães, 2010). In 1998 the Programme for the Development and Expansion of Adult Education and Training was created and in 1999 the National Agency of Adult Education and Training was established, responsible for the implementation of the processes of recognition of prior learning and adult education and training courses. After 2000, with the implementation of adult education and training policy resulting from the Lisbon Strategy, new professionals appeared. These professionals were working essentially in training, mediation, management and assessment of the educational and training careers of low schooling adults. 
In 2001 a national network of centres of recognition, validation and certification of competences was created and the staff was defined by legal guidance (Ordinance $\mathrm{n}^{\circ}$ 1082-A/2001, September 8). The number of the recognition, validation and certification of competences centres increased and in 2010 there were 454 New Opportunities Centres (the name of these centres changed in 2008), 44\% of which were located in basic and secondary level schools and 19\% (of which) belonged to vocational training centres (Agência Nacional para a Qualificação, 2010).

In the above mentioned New Opportunities Centres, adults' guidance and counselling activities were developed, guiding adults to qualification pathways and processes of recognition of prior learning. Legal guidance about the New Opportunities Centres was published, defining the pedagogical staff and their qualification, professional profile and function description (Ordinance $n^{\circ} 370 / 2008$, May 21). The pedagogical teams of these New Opportunities Centres were composed of a director, a coordinator, vocational counselling technicians, recognition of prior learning (RPL) professionals, trainers and administrative technicians. According to the mentioned Ordinance, the RPL professionals, an adult educator category, had to hold higher level academic qualification, they had to possess knowledge about the used methodologies and experience in adult education and training, namely in competence assessment and learning reflexive portfolios. However, the mentioned legal guidance didn't define a specific academic qualification for these adult educators. In general, adult educators had to hold a licentiate degree as a minimum requirement and preferably previous professional experience with adults to begin working in this field.

In February of 2011, 9074 adult educators were working in New Opportunities Centres, 4648 as trainers, 1900 as RPL professionals, 545 as vocational counselling technicians and 453 as coordinators (Gomes, 2011). Moreover, there were still RPL tutors and directors. At the time the process of recognition of prior learning was the offer that mobilised more adults in adult education processes (Agência Nacional para a Qualificação, 2008). According to Guimarães (2009), at the time there were more adult educators than ever recorded in Portugal. The increasing number of adult educators led to the emergence of associative practices as a way of affirming this professional field.

In 2012 and 2013, the New Opportunities Centres were closed due to some changes in the Portuguese adult education framework determined by the current government, and thousands of adult educators became unemployed. In the beginning of 2014, new adult learning centres were opened, now named Centres of Qualification and Vocational Teaching. These new adult centres aim to guide youth and adults with a low level of qualification to get competences to increase their employability and also to develop recognition of prior learning. The adult educators who are working in these centres are called technicians of guidance, recognition and validation of competences and their tasks are centred in two domains: vocational guidance and recognition of prior learning.

\subsection{Training and skills of Portuguese adult educators involved in processes of recognition of prior learning}

In the 1990s there was a paradigm shift in the field of adult education policies, moving from the influence of lifelong education (éducation permanente) to lifelong learning (Canário, 2003). The guiding documents of lifelong learning, especially the Memorandum on Lifelong Learning, prepared by the European Commission in 2000 , revealed the importance of investing in public policies of recognition of prior 
learning (Cavaco, 2009). This guidance was referred to at the International Conference of Adult Education held in Hamburg in 1997. The Global Agenda (Dale, 2001) and the European Agenda for Education, dictated by supranational bodies, such as UNESCO and the European Union, have contributed to the emergence of public policies of recognition of prior learning in several European countries, including Portugal, in the passage from the twentieth to the twenty-first century (Cavaco, 2009).

In 2001, in Portugal, a national network of recognition of prior learning centres was created, starting an educational practice based on valorisation of experiences and learning from non-formal and informal educational settings. These educational practices contributed to an increase in the diversity and complexity of the field of adult education, which resulted in the reconfiguration of the professional field of adult educators with the changing role of trainers and the emergence of new categories of adult educators (Cavaco, 2007).

The current research underdevelopment focuses on adult educators working in the recognition of prior learning, especially in a professional category named RPL professionals. From a theoretical point of view, this research uses elements from several knowledge fields, mainly adult education and sociology of education. The main aims of this research are to understand the paths and the professional activity of those adult educators and also their competences and qualifications. This study intended to answer the following questions: Who are these adult educators? What are the competences of adult educators? How do they learn to do their work?

From an epistemological point of view, the research is based on a comprehensive perspective, which aims to describe, interpret and analyse critically (Gonçalves, 2010) the development and professional activity of adult educators responsible for the recognition of prior learning. The comprehensive perspective is useful to explain contexts characterised by deep changes in social practices (Guerra, 2006). From a methodological point of view, the qualitative approach was used. The method used for collecting data was the biographical interview (Pineau and Le Grand, 2002) since this kind of interview allows understanding of the relationship that individuals have with the social and historical world through their biographical activity and the study of meanings they give to their experiences (Delory-Momberger, 2012). The empirical data of this study consist of thirty-two biographical interviews of RPL professionals. Audio recordings of the interviews were done with the subjects' consent. A thematic content analysis (Bardin, 1995) was the technique used to analysis the information from the interviews.

\subsection{Adult educators' background}

Data collected revealed that 27 of the 32 interviewed RPL professionals were women. This evidence is consistent with that observed by Leclercq (2005) with regard to specialised trainers in basic training, a group composed mostly by females. Also Guimarães (2009), according to a sample of adult educators who were attending continuing education at the University of Minho, states that the majority of them were female.

The majority of adult educators held higher education degrees in social and human sciences; specifically, 13 held degrees in Psychology, 4 in Education Sciences, 3 in Sociology, 2 in Social Service and 1 in Anthropology. Moreover, 9 adult educators held education degrees in teaching. Similar results were obtained by Guimarães (2009) in research done with trainers from centres of recognition of prior learning (named New Opportunities Centres). In this case, they also held degrees in human and social sciences. 


\subsection{Development and professional activity}

The adult educators that were interviewed had previous professional experience in a variety of fields, such as Psychology, professional training, human resources and teaching. As stated by one interviewee: "I used to work with visually challenged people because I studied Psychology, specifically the Psychology of social exclusion. So, I have worked with people with some sort of disability, and I also worked for ACAPO [Portuguese association for blind and visually impaired people]." (RPL professional).

Regarding the professional trajectories of those adult educators (from completion of their graduation until the moment they started performing this professional role), they weren't generally straightforward but punctuated by incursions (some lasting several years) in other professional areas. This is in agreement with what was observed by Andersson, Köpsén, Larson and Milana (2013) on their research on the qualification paths and professional trajectories of adult educators in two European countries, Sweden and Denmark. In this study, these authors found that there were adult educators who had previously worked in other areas and that, due to events that occurred in their lives, changed occupation coming to adult education; whereas others became adult educators due to the inability to get a job in their academic qualification area.

As far as training was concerned, adult educators were divided by the areas in which they mainly invested. Some preferred to focus on training related to their professional activity or area of academic studies as told by an interviewee: "I have done postgraduate training and this year I will finish my specialisation in Brief Psychotherapies. I have also done post graduate training in Sexology. Always, in my area of study, Psychology. I have never done anything related to adult education and training. I always prefer to focus on Psychology." (RPL professional).

Others have opted for other types of training, namely at a postgraduate level, which are related to the field of adult education and training: "I'm specialising in adult education and training, at the Institute of Education (...) I really wanted to acquire more skills in this field in order to evolve at a professional level." (RPL professional). This option was taken to fulfil a need to acquire further knowledge that could allow them to develop their skills and become more proficient in their activity.

These adult educators had technical competences and behavioural and relational skills. Firstly, they had knowledge about biographical methodologies and competences assessment. But the main highlighted competences were relational skills, as referred to by an interviewee: "I think there are some necessary characteristics - actively listening to people, being able to be tolerant and patient. Above all, it's a process of self-motivation." (RPL professional).

These adult educators were essentially focused on the development of the tasks defined in that process. As argued in interviews they viewed themselves as responsible for the process, which aims for the competences certification of the adults with low level of schooling: "My job here is to manage the group's functioning; I'm the one who controls the group's planning, dates, sessions, as well as extra appointments that might need to be supported by myself or the trainers. I also give some support to biography development - and it has to be done in a plain and accessible language so that I can help these people to write down their competences they have acquired throughout their lives as well as this work's structure and organisation." (RPL professional). 
They help adults to think about their life experiences and learning, they support them during the entire process. Following this understanding, an interviewee mentioned the following: "Working the candidate's motivations, making sure they never become demotivated, working with people's expectations, uncovering what their competences are, since they have a hard time realising what they actually know and how to write it down for the record. We need to apply some skills and methods that make them understand what is it they are going to write on that portfolio. It's a competence-uncovering process: to understand the candidate's history, what did he go through and which of his experiences are useful for this process." (RPL professional). These adult educators also have a mediator role in the problem resolution between the several actors involved in the process, mainly between adults and trainers. They stressed skills such as communication, active listening, motivation, emotional support, conflict management, and mediation between adults and others professionals such as trainers.

Those professionals learned to become adult educators in several ways. Learning how to do the work was achieved both through reading several publications dedicated to recognition of prior learning and by moving from theory to professional practice through a self-training process: "I read a lot of stuff, large amounts of documentation and studies that were already published when I first started back in January 2010. And I obviously studied the benchmarks, because I had to." (RPL professional).

In other cases, knowledge was acquired by interacting with peers with professional experience, who worked as informal trainers, through the systematic presentation and explanation of the procedures through which competences are recognised, as well as active observation of these experienced professional practices. As stated by an interviewee: "When I first came here I learned as much as I could about all the activities, I had co-workers who supported me and also taught me some of their practical skills. I also observed some of my colleagues' sessions. The whole thing is actually quite intuitive." (RPL professional).

These adult educators have also learned to perform their professional tasks by attending training courses provided by the supervising institution (the National Adult Education and Training Agency [NAETA]), followed by the National Qualification Agency [NQA]) as well as other certified institutions (such as the New Opportunities Centres directed or co-directed by the Institute for Employment and Vocational Training). As mentioned by an interviewee: "I started working in early November and I remember that during that year I had received training from the National Adult Education and Training Agency. Over several days I learned everything about referential, competences balance methodologies, jury sessions and about how jury sessions should take place. All of this really helped me." (RPL professional).

Adults also learn by drawing from their pool of acquired experiences, which they activate whenever the need arises (Boutinet, 2001). Within this line of reasoning, an adult educator, when inquired, said that: "I did it thanks to my background in Psychology and also by trying to understand, by studying the manuals and applying my experience to the subject at hand (...) I applied my experience, my knowledge and, of course, my background as a Clinical Psychologist, so that I could, as they say, take those criteria and recognition of prior learning work methods and make them my own." (RPL professional). According to Pineau (1991), we can say that adult educators learn through eco-training, hetero-training and experiential training, with direct and reflected contact with the learning situations (Josso, 1991). 
These adult educators believed that their job was essential for the recognition of prior learning, by fulfilling the role of organisers for all of the work carried out by both trainers and adults. They saw themselves as mediators for both the recognition of prior learning process and the relationship between the adults and their trainers. They highlighted as core competences their interpersonal skills, focusing on support, motivation and reinforcement: "For me, being professional is not about being in a training room and encouraging the discovery of competences. It's a lot more than that and essentially this is our main job: being available for candidates." (RPL professional).

The professional activity developed by these adult educators can be included in what Demailly (2008) designates as relational activities, which distinguish themselves by their need for relational skills. They faced their professional activity as essentially centred on support throughout the recognition of acquired experiences, leading and guiding the tasks and activities that build the entire process of recognition of prior learning, but also being mediators and support and motivation providers.

How the performance of this professional activity is viewed varies over time from an early "idealist" perspective to a realist outlook brought on by political and administrative demands imposed by both the institutions responsible for the New Opportunities Centres and by social constraints. As argued in interviews: "When I first got here I was looking for strategies and promoting certain types of helpful activities and situations (...) these days, I am not in the mood for that because there is no motivation. The fact that we don't know what is going to happen to us and the fact that the government, the country itself disregards us... it just makes me unhappy, because we've done a lot and it was all for nothing." (RPL professional).

The experience of living in a situation of employment instability, coupled with the lack of social recognition and appreciation can lead to demotivation and loss of work involvement. It's important to remark that adult educators involved in processes of recognition of prior learning lived in an unstable situation regarding their employment, which culminated in the feared outcome of unemployment when, due to measures of the current Government, the centres for adult education where they worked were closed in late 2012 and early 2013. Following the decision of cancellation of funding for all New Opportunities Centres, the directors of those centres began to require their extinction, according to what is ruled by the Ordinance 370/2008 dated 21 of May (Article 24, n.2), due to inability to financially fund themselves. As stated by the Ordinance 135-A/2013 of 28 of March, the "New Opportunities Centres are considered extinct from March 31, 2013" (Article 35, n. 3).

\section{$5 \quad$ Final Remarks}

Adult educators' qualification has a key role in the implementation of efficient adult education programmes. Although the field work of all the adult educators on which this research focused has been the process of recognition of prior learning, we must point out the differences that exist at the level of their basic training, further training and previous career paths. Regarding this, it is important that the responsible public authorities take into account the diversity of adult educators' paths and the need to invest in their training. Considering the adult educators working in recognition of prior learning, Travers and Harris (2014) pointed out that the training of these practitioners should include areas such as formative and cumulative assessment, philosophical underpinnings and approaches to advising and tensions between them, ways of influencing the learner, the concept of equivalence in recognition of prior learning assessment, and the nature of objectivity, reliability and validity in assessment. 
Similar to what happens in other European countries (Bechtel, 2008; Lattke and Nuissl, 2008; Milana, 2010) in Portugal adult educators are a heterogeneous group. Although adult educators can work in several fields, in the last decade they have mainly worked in vocational training (as trainers) and in the recognition of prior learning. Therefore, in Portugal, the professionalisation of adult educators is incipient and "the profession of adult educator has never really been structured" (Guimarães, 2009). Adult educators have diverse backgrounds and career paths, some of which use relational and communication skills acquired in their basic training or transferred from previous professional experience unrelated to this career. To promote the quality of adult education, without it depending on skills that just a few adult educators may have purchased on an ad hoc basis, it is mandatory to invest in their continuing training. Promoting employment stability and social recognition may contribute so that these professionals invest more in their qualification in this field rather than acquire training in diverse areas related to basic training.

The political disinvestment in the field of adult education that has occurred in the last few years, in Portugal, has led to the unemployment of a considerable part of the professionals involved in adult education activities, particularly in the recognition of prior learning process. The unstable employment situation of adult educators can cause both a disinvestment in their qualification process, and in the field of adult education. Moreover, some adult educators that have worked in recognition of prior learning processes, who are now unemployed or working in other areas, are at risk of losing a whole set of knowledge and skills acquired through their professional practice in adult education and through their qualification processes in this field. Moreover, the dismantling of adult education centres has been contributing to the loss of organizational knowledge created, and to the destruction of the networks established between educational institutions, society and adults with a low level of schooling.

In political terms it would be important to ensure the continuity of adult education policies. Changes should be based on solid research, taking into account the several participants in the process, and it should mainly focus on the factors that can be improved, keeping the processes that have produced good results. Investing in the training of adult educators, building structured careers and secure stable employment situations, resistant to political and economic instability, are indispensable conditions for providing quality to adult education. In order to improve adult education, the implementation of policies based on evidence is recommended. Moreover, policies should include the valorisation of adult educators, enabling the creation of structured careers and their professional development. 


\section{References}

Agência Nacional para a Qualificação (2008). The development and state of the art of adult learning and education (ALE). National report of Portugal. Accessed 1 July 2014 from: http://www.unesco.org/fileadmin/MULTIMEDIA/INSTITUTES/UIL/confintea/pdf/National_Reports/Europe\%20\%20North\%20America/Portugal.pdf.

Agência Nacional para a Qualificação (2010). Linhas orientadoras para o futuro da Iniciativa Novas Oportunidades [Guidelines for the future of the New Opportunities Iniciative]. Lisboa: Agência Nacional para a Qualificação.

Andersson, P.; Köpsén, S.; Larson, A. \& Milana, M. (2013). Qualification paths of adult educators in Sweden and Denmark. Studies in Continuing Education, 35(1), 102-118.

Antunes, F. (2008). Nova ordem educacional, espaço europeu de educação e aprendizagem ao longo da vida: actores, processos, instituições. Subsídios para debate [New educational order, European space of education and lifelong learning: actors, processes, institutions. Subsidies for debate]. Coimbra: Edições Almedina.

Bardin, L. (1995). Análise de conteúdo [Content analysis]. Lisboa: Edições 70.

Bechtel, M. (2008). Competence profiles for adult and continuing education staff in Europe: Some conceptual aspects. In E. Nuissl \& S. Lattke (Eds.), Qualifying adult learning professionals in Europe (pp. 45-61). Bielefeld: W. Bertelsmann Verlag.

Biesta, G. (2012). Have Lifelong Learning and Emancipation Still Something to Say to Each Other?. Studies In The Education Of Adults, 44(1), 5-20.

Boutiné, J. P. (2001). Vida adulta em formação permanente: da noção ao conceito [Adulthood in continuing training: from the notion to the concept]. In P. Carré \& P. Caspar (Dirs.), Tratado das Ciências e das Técnicas da Formação [Treaty of Sciences and Techniques of Training] (pp. 185-206). Lisboa: Instituto Piaget.

Canário, R. (2003). A “aprendizagem ao longo da vida". Análise crítica de um conceito e de uma política [The "lifelong learning". Critical analysis of a concept and a policy]. In R. Canário (Org.), Formação e situações de trabalho [Training and working situations] (pp. 189-207). Porto: Porto Editora.

Canário, R. (2008). Educação de adultos. Um campo e uma problemática [Adult education. A field and a problematic]. Lisboa: Educa.

Cavaco, C. (2007). Reconhecimento, validação e certificação de competências: Complexidade e novas actividades profissionais [Recognition, validation and certification of competences: Complexity and new professional activities]. Sísifo. Revista de Ciências da Educação, 2, 21-34. Accessed 10 July 2013 from: http://sisifo.fpce.ul.pt/pdfs/sisifo0201.pdf.

Cavaco, C. (2009). Adultos pouco escolarizados. Políticas e práticas de formação [Adults with a low level of schooling. Training policies and practices]. Lisboa: Educa.

Commission of the European Communities (1993). Growth, competitiveness, employment. The challenges and ways forward into the 21st century. Luxembourg: Office for Official Publications of the European Communities.

Commission of the European Communities (1995). Teaching and learning: Towards the learning society. Luxembourg: Office for Official Publications of the European Communities. 
Delory-Momberger, C. (2012). Abordagens metodológicas na pesquisa biográfica [Methodological approaches in biographical research]. Revista Brasileira de Educação, 17(51), 523-536.

Demailly, L. (2008). Politiques de la relation. Approche sociologique des métiers et activités professionnelles relationnelles. Villeneuve d'Ascq: Presses Universitaires du Septentrion.

Duvekot, R. (2014). Lifelong learning policy and RPL in the learning society: The promise of Faure? In J. Harris, C. Wihak \& J. V. Kleef (Eds.), Handbook of the recognition of prior learning. Research into practice (pp. 65-85). Leicester: National Institute of Adult Continuing Education.

Egetenmeyer, R. (2010). Professionalisation in adult education: a European perspective. In R. Egetenmeyer \& E. Nuissl (Eds.), Teachers and trainers in adult and lifelong learning. Asian and European perspectives (pp. 31-44). Frankfurt am Main: Peter Lang.

Egetenmeyer, R. \& Käpplinger, B. (2011). Professionalisation and quality management: struggles, boundaries and bridges between two approaches. European Journal for Research on the Education and Learning of Adults, 2(1), 21-35.

European Commission (2006, 23 October). Communication from the Commission. Adult learning: It is never too late to learn. Accessed 29 December 2014 from: http://eur-lex.europa.eu/LexUriServ/LexUriServ.do?uri=COM:2006:0614:FI$\mathrm{N}: \mathrm{EN}: \mathrm{PDF}$.

European Commission (2007, 27 September). Communication from the Commission to the Council, the European Parliament, the European Economic and Social Committee and the Committee of the Regions. Action Plan on Adult learning. It is always a good time to learn. Accessed 29 December 2014 from: http://eurlex.europa.eu/legal-content/EN/TXT/PDF/?uri=CELEX:52007DC0558\&from $=\mathrm{EN}$.

Faure, E.; Herrera, F.; Kaddoura, A.; Lopes, H.; Petrovsky, A. V.; Rahnema, M. et al. (1972). Learning to be: the world of education today and tomorrow. Paris: UNESCO.

Freynet, P. (2008). Modern processes of production, distribution and use of knowledge. In E. Nuissl \& S. Lattke (Eds.), Qualifying adult learning pro-fessionals in Europe (pp. 45-61). Bielefeld: W. Bertelsmann Verlag.

Gomes, M. C. (2011). Desenvolvimento organizacional dos Centros Novas Oportunidades [Organizational development of New Opportunities Centers]. Keynote presented at $1^{\text {th }}$ Self-Evaluation Congress of Educational and Training Organizations. Lisbon: Portuguese Catholic University.

Gonçalves, T. (2010). Investigar em educação: Fundamentos e dimensões da investigação qualitativa [Research in education: Foundations and dimensions of the qualitative research]. In M. G. Alves \& N. R. Azevedo. (Eds.), Investigar em educação: Desafios da construção de conhecimento e da formação de investigadores num campo multi-referenciado [Research in education: Challenges of the knowledge building and the training of researchers in a multi-referenced field] (pp. 39-63). Lisboa: UIED.

Guerra, I. C. (2006). Pesquisa qualitativa e análise de conteúdo: sentidos e formas de uso [Qualitative research and content analysis: meanings and ways of using]. Estoril: Princípia.

Guimarães, P. (2009). Reflections on the Professionalisation of Adult Educators in the Framework of Public Policies in Portugal. European Journal of Education, 44(2), 205-219. 
Guimarães, P. (2010). Educadores de adultos em Portugal: políticas fragmentadas, identidades em mudança [Adult educators in Portugal: fragmented policies, identities in changing]. Ensaio: Avaliação e Políticas Públicas em Educação, 18(69), 775-794.

Josso, M. C. (1991). L'expérience formatrice: un concept en construction. In B. Courtois \& G. Pineau (Coords.), La formation expérientielle des adultes (pp. 191-199). Paris: La Documentation Française.

Jütte, W.; Nicoll, K. \& Olesen, H. S. (2011). Editorial: Professionalisation - the struggle within. European Journal for Research on the Education and Learning of Adults, 2(1), 7-20.

Lattke, S. \& Nuissl, E. (2008). Qualifying professionals for adult learning in Europe. In E. Nuissl \& S. Lattke (Eds.), Qualifying adult learning professionals in Europe (pp. 7-18). Bielefeld: W. Bertelsmann Verlag.

Leclercq, V. (2005). La professionnalisation du formateur spécialisé en formation de base. Education Permanente, 164(3), 105-118.

Lima, L. (2008). A educação de adultos em Portugal (1974-2004): Entre as lógicas da educação popular e da gestão de recursos humanos [Adult education in Portugal (1974-2004): Between the logics of popular education and the human resources management]. In R. Canário \& B. Cabrito (Org.), Educação e formação de adultos. Mutações e convergências [Adult education and training. Mutations and convergences] (pp. 31-60). Lisboa: EDUCA.

Milana, M. (2010). BAEA: Becoming Adult Educators in the European Area. Synthesis research report. Copenhagen: Danish School of Education, Aarhus University.

Nuissl, E. \& Lattke, S. (2008). Qualifying adult learning professionals in Europe. Bielefeld: W. Bertelsmann Verlag.

Ordinance 370/2008, May 21.

Ordinance 135-A/2013, March 28.

Pineau, G. (1991). Formation expérientielle et théorie tripolaire de la formation. In B. Courtois \& G. Pineau (Coords.), La formation expérientielle des adultes (pp. 29-40). Paris: La Documentation Française.

Pineau, G. \& Le Grand, J. (2002). Les histoires de vie: Que sais-je? Paris: PUF.

Research voor Beleid (2010). Key competences for adult learning professionals. Contribution to the development of a reference framework of key competences for adult learning professionals. Final report. Accessed 29 December 2014 from: http://www.ginconet.eu/sites/default/files/Key_Competences_For_Adult_Educators.pdf.

Research voor Beleid \& PLATO (2008). ALPINE - Adult Learning Professions in Europe. A Study of the current situation, trends and issues. Final report. Accessed 29 December 2014 from: http://www.ne-mo.org/fileadmin/Dateien/public/MumAE/adultprofreport_en.pdf.

Travers, N. L. \& Harris, J. (2014). Trends and issues in the professional development of the RPL practitioners. In J. Harris, C. Wihak \& J. V. Kleef(Eds.), Handbook of the recognition of prior learning. Research into practice (pp. 233-258). Leicester: National Institute of Adult Continuing Education.

Van Dellen, T. \& Van der Kamp, M. (2008). Work domains and competencies of the European adult and continuing educator. In E. Nuissl \& S. Lattke (Eds.), Qualifying adult learning professionals in Europe (pp. 63-74). Bielefeld: W. Bertelsmann Verlag. 